Shaye J.D. Cohen

\title{
The Significance of Yavneh and Other Essays in Jewish Hellenism
}

[Die Bedeutung von Yavne und andere Studien zum jüdischen Hellenismus]

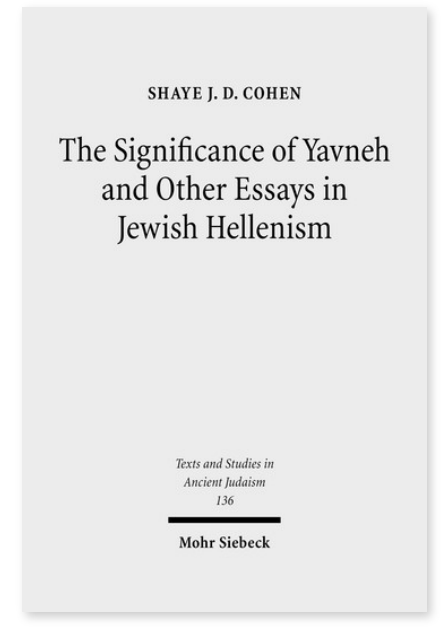

2010. XV, 614 Seiten. TSAJ 136

ISBN 978-3-16-151469-2

DOI 10.1628/978-3-16-151469-2

eBook PDF 214,00€

ISBN 978-3-16-150375-7

Leinen $214,00 €$
Veröffentlicht auf Englisch.

Der vorliegende Band versammelt 30 Studien Shaye J.D. Cohens, die zwischen 1980 und 2006 erschienen sind. Darin behandelt er eine große Vielfalt an Themen und Texten: den jüdischen Hellenismus, Josephus, die Synagoge, den Übertritt zum Judentum, Blut und Unreinheit, die Grenze zwischen Judentum und Christentum. Diese Studien verbindet ihre sprachwissenschaftliche Ausrichtung. Cohen untersucht schwer verständliche Passagen in jüdischen und christlichen Texten. Die Aufsätze sind durch die Annahmen verbunden, daß die antike Welt ein einziges Kontinuum darstellte, daß das antike Judentum in all seinen Ausdrucksformen und seiner Vielfalt hellenistisch imprägniert war und daß die Texte in hebräischer und in griechischer Sprache durch eine gemeinsame Welt von Themen und Gegenständen verbunden sind.

Inhaltsübersicht

\section{Jewish Hellenism}

The Beauty of Flora and the Beauty of Sarai - Sosates the Jewish Homer - The Destruction: From Scripture to Midrash - The Significance of Yavneh - Patriarchs and Scholarchs - False Prophets (4Q339), Netinim (4Q340), and Hellenism at Qumran

\section{Josephus}

Josephus, Jeremiah, and Polybius - History and Historiography in the Against Apion of Josephus - Masada: Literary Tradition, Archaeological Remains, and the Credibility of Josephus - Parallel Historical Tradition in Josephus and Rabbinic Literature Alexander the Great and Jaddus the High Priest According to Josephus - Respect for Judaism by Gentiles in the Writings of Josephus - loudaios to genos and Related Expressions in Josephus

\section{Synagogues and Rabbis}

Epigraphical Rabbis - Pagan and Christian Evidence on the Ancient Synagogue - Were Pharisees and Rabbis the Leaders of Communal Prayer and Torah Study in Antiquity? The Evidence of the New Testament, Josephus, and the Early Church Fathers The Place of the Rabbi in the Jewish Society of the Second Century

\section{Conversion and Intermarriage}

Was Judaism in Antiquity a Missionary Religion? - Adolf Harnack's The Mission and Expansion of Judaism: Christianity Succeeds where Judaism Fails - Is 'Proselyte Baptism' Mentioned in the Mishnah? The Interpretation of M. Pesahim 8:8 - The Conversion of Antoninus - On Murdering or Injuring a Proselyte - Solomon and the Daughter of Pharaoh: Intermarriage, Conversion, and the Impurity of Women

Women and Blood

Menstruants and the Sacred in Judaism and Christianity - Purity, Piety, and Polemic: Medieval Rabbinic Denunciations of 'Incorrect' Purification Practices - A Brief History of Jewish Circumcision Blood

Judaism and Christianity

Judaism without Circumcision and 'Judaism' without 'Circumcision' in Ignatius - Between Judaism and Christianity: the SemiCircumcision of Christians According to Bernard Gui, his Sources, and R. Eliezer of Metz - Does Rashi's Torah Commentary Respond to Christianity? A Comparison of Rashi with Rashbam and Bekhor Shor - A Virgin Defiled: Some Rabbinic and Christian Views on the Origins of Heresy

Shaye J.D. Cohen Born 1948; 1975 PhD in Ancient History, Columbia University; 1974-91 Professor at the Jewish Theological Seminary in New York; 1991-2001 Professor at Brown University; since 2001 Littauer Professor of Hebrew Literature and Philosophy (Jewish Studies), Harvard University.

Jetzt bestellen:

https://mohrsiebeck.com/buch/the-significance-of-yavneh-and-other-essays-in-jewish-hellenism-9783161514692?no_cache=1 order@mohrsiebeck.com

Telefon: $+49(0) 7071-923-17$

Telefax: $+49(0) 7071-51104$ 